\title{
PENGEMBANGAN TELEGRAM BOT ENGINE MENGGUNAKAN METODE WEBHOOK DALAM RANGKA PENINGKATAN WAKTU LAYANAN E-GOVERNMENT
}

\author{
Moh. Anshori Aris Widya*, Primaadi Airlangga**
}

Fakultas Teknologi Informasi, Universitas K.H. A. Wahab Hasbullah

Correspondence Author: anshoriaris@unwaha.ac.id

\begin{tabular}{|c|c|}
\hline Info Artikel : & ABSTRACT \\
\hline $\begin{array}{l}\text { Sejarah Artikel : } \\
\text { Menerima : } \\
21 \text { Sept } 2020 \\
\text { Revisi : } \\
03 \text { Okt } 2020 \\
\text { Diterima : } \\
10 \text { Okt } 2020 \\
\text { Online : } \\
23 \text { Okt } 2020\end{array}$ & $\begin{array}{l}\text { E-Government services nowadays must make it easierfor the public. Request } \\
\text { for E-Government services that can be done anywhere at any time is an } \\
\text { innovation that can shorten service time and can reduce queues at government } \\
\text { offices. This service model uses ICT (Information Communication Technology) } \\
\text { media which has high flexibility. An example are the Website and Mobile } \\
\text { platforms. The website is easy to use with a browser and the mobile } \\
\text { application is used with a smartphone. Even though it has high flexibility, } \\
\text { there are several weaknesses on both platforms such as the website display } \\
\text { which must be responsive and the mobile application which must be user } \\
\text { friendly and have a high user experience. This is because sometimes mobile } \\
\text { applications different for another in terms of mechanism, appearance and } \\
\text { usage method. A type of mobile application that popular and widely used by } \\
\text { the public is Chat Apps or Instant Messaging. This type of mobile application } \\
\text { has an easy way to use and a user friendly for everyone. Almost all } \\
\text { smartphone users also use Instant Messaging. Basedon these advantages, the } \\
\text { concept of the convenience of people in sending messages (chatting) with this } \\
\text { type of application is integrated with the conceptofE-Government services to } \\
\text { make it easier and shorten the time of E-Government services. Telegram } \\
\text { Instant Messaging as a mobile application of this type was chosen because it } \\
\text { has a Bot API or Bot Engine feature that is open license and can be easily } \\
\text { integrated with various other devices in the E-Government services } \\
\text { framework. Development Method System in this research is Research and } \\
\text { Development (R\&D) }\end{array}$ \\
\hline $\begin{array}{l}\text { Keyword: } \\
\text { E-Government; } \\
\text { Bot Engine; } \\
\text { Telegram; } \\
\text { Webhook. }\end{array}$ & INTISARI \\
\hline $\begin{array}{l}\text { Kata Kunci : } \\
\text { E-Government; } \\
\text { Bot Engine; } \\
\text { Telegram; } \\
\text { Webhook. }\end{array}$ & $\begin{array}{l}\text { Layanan E-Government saat ini harus semakin memudahkan masyarakat. } \\
\text { Request layanan E-Government yang dapat dilakukan dimana saja kapan saja } \\
\text { merupakan sebuah inovasi yang dapat mempersingkat waktu layanan serta } \\
\text { dapatmengurangi antrian pada kantor pemerintahan. Model layanan tersebut } \\
\text { menggunakan media ICT (Information Communication Technology) yang } \\
\text { memiliki flexibilitas yang tinggi. Salah satu contohnya adalah platform } \\
\text { Website maupun Mobile. Website mudah digunakan dengan bantuan browser } \\
\text { dan aplikasi mobile digunakan dengan bantuan smartphone. Walaupun } \\
\text { memiliki flexibiltas yang tinggi, terdapat beberapa kelemahan pada kedua } \\
\text { platform tersebut seperti tampilan website yang harus responsive dan aplikasi } \\
\text { mobile yang harus user friendly serta memiliki user experience tinggi. Hal } \\
\text { tersebut disebabkan terkadang antara aplikasi mobile satu dengan yang lain } \\
\text { berbeda dari segi mekanisme, tampilan maupun cara penggunaan. Salah satu } \\
\text { aplikasi mobile yang cukup populer serta banyak digunakan masyarakat } \\
\text { adalah Chat Apps atau Instant Messaging. Aplikasi mobile jenis ini memiliki }\end{array}$ \\
\hline $\begin{array}{l}\text { ISSN Print } \\
\text { ISSN Online }\end{array}$ & $\begin{array}{l}141 \\
942\end{array}$ \\
\hline
\end{tabular}




\begin{tabular}{|l|l|}
\hline cara penggunaan yang mudah serta tampilan yang user friendly bagi semua \\
orang. Hampir seluruh pengguna smartphone juga menggunakan Instant \\
Messaging. Berdasarkan keunggulan inilah maka konsep kemudahan orang \\
dalam melakukan pengiriman pesan (chatting) dengan aplikasi jenis ini \\
diintegrasikan dengan konsep layanan E-Government untuk semakin \\
memudahkan serta mempersingkat waktu layanan E-Government. Instant \\
Messaging Telegram sebagai aplikasi mobile jenis ini dipilih dikarenakan \\
memilikifitur Bot API atau Bot Engine yang bersifat open licence serta dapat \\
dengan mudah diintegrasikan dengan berbagai perangkat lain dalam rangka \\
layanan E-Government. Metode pengembangan sistem yang digunakan dalam \\
penelitian ini adalah Metode Research and Development $(R \& D)$
\end{tabular}

\section{PENDAHULUAN}

Layanan administrasi pemerintahan saat ini sangat bervariasi, mulai dari layanan yang bersifat konvensional hingga menggunakan media Information Communication Technology (ICT). Layanan konvensional memiliki keterbatasan pada pemberian layanan yang hanya bisa dilakukan secara khusus di kantor pemerintahan setempat dan memaksa pihak yang berkepentingan untuk harus datang langsung ke tempat layanan. Selain itu layanan jenis ini juga membutuhkan waktu layanan yang lama dikarenakan proses antri, proses pelayanan hingga selesai dan semua itu menyita waktu produktif warga yang berkepentingan. Sedangkan penggunaan model layanan ICT sedikit berbeda, pihak yang berkepentingan tidak harus datang ke tempat layanan melainkan cukup menggunakan media ICT dalam melakukan request layanan. Model layanan ICT seperti ini juga harus mempersingkat waktu, tidak lagi menyita waktu produktif warga apalagi proses antrian yang juga rawan menjadi pemicu penyebaran virus Covid-19.

Meskipun media ICT seperti website yang dapat diakses melalui banyak perangkat seperti Personal Computer (PC) dan smartphone, akan tetapi media-media ini tetap memiliki beberapa kekurangan. Media website memiliki kekurangan pada tampilan dimana jika website tersebut tidak memiliki kemampuan responsive, maka interface yang dihasilkan tidak memuaskan bahkan bisa membuat informasi dan layanan tidak mudah dimengerti bahkan tidak dapat diakses oleh pengguna.

Aplikasi mobile (Mobile Apps) baik Android, iOS maupun Windows Phone sering digunakan sebagai alternatif karena memiliki flexibiltas yang tinggi. Namun bukan berarti aplikasi mobile tidak memiliki kekurangan. Secara umum aplikasi mobile antara satu dengan yang lain memiliki tampilan serta cara penggunaan yang berbeda sehingga dibutuhkan pembelajaran dalam penggunaannya.

Instant Messaging (IM) merupakan fasilitas komunikasi chatting untuk para pengguna internet. Dengan menggunakan fasilitas ini, user dapat berkomunikasi dengan cara mengirimkan pesan berupa text dengan user lain [1]. Aplikasi jenis ini antara lain Whatsapp, Telegram, Line, Facebook Messenger dan lain sebagainya. Tingginya pengguna Instant Messaging dapat diartikan juga bahwa banyak masyarakat yang sudah terbiasa menggunakan aplikasi jenis ini dalam kehidupan sehari-hari sehingga salah satu kelemahan aplikasi mobile yang disebutkan di atas telah teratasi dengan sendirinya. Kebiasaan masyarakat dalam berkomunikasi menggunakan berbagai macam Instan Messaging yang ada tersebut, menjadikan dasar peneliti ingin mengembangkan sebuah layanan e-Government menggunakan salah satu Instant Messaging yaitu Telegram dengan memanfaatkan fitur Bot Engine menggunakan metode Webhook.

Telegram didirikan pada tahun 2013 oleh dua orang bersaudara yang bernama Nikolai dan Pavel Durov yang bertujuan untuk menyediakan aplikasi IM yang dapat digunakan berkirim pesan dengan aman bagi pengguna yang tidak mengerti teknologi. Telegram memungkinkan pengguna untuk mengirim pesan teks, pesan suara dan berkomunikasi dalam grup [2]. Salah satu kelebihan aplikasi Telegram dibandingkan dengan aplikasi sejenis lainnya adalah adanya fitur berupa API (Application Programming Interface) untuk masyarakat luas [3]. Bagi yang ingin mengembangkan sistem berbasis Telegram, disediakan 2 jenis API yaitu Bot API (Bot Engine) dan TDLib (Telegram Database Library) [4]. Bot Engine merupakan aplikasi pihak ketiga yang dapat 
berinteraksi secara langsung menggunakan token dengan Bot Telegram melalui pengiriman pesan, perintah (command) dan inline request. Bot Engine dapat digunakan sebagai berita dan notifikasi khusus, dapat diintegrasikan dengan layanan lainnya, dapat menerima pembayaran dari user telegram lainnya, dapat dibuat sebagai alat khusus, dapat dibuat sebagai Game (Single maupun Multiplayer), dapat digunakan sebagai layanan media sosial, dapat digunakan sebagai layanan virtual lainnya [4].

Webhook merupakan salah satu metode komunikasi informasi dalam Bot Engine Telegram. Secara keseluruhan Bot Engine Telegram menyediakan 2 metode komunikasi yaitu Long Polling dan Webhook [5]. Dibandingkan dengan Long Polling, Webhook memiliki mekanisme komunikasi yang lebih singkat sehingga lebih cepat untuk digunakan dalam merespon maupun memproses informasi. Pada metode Long Polling, informasi disediakan oleh Bot Engine Telegram berdasarkan request yang dilakukan oleh pihak ketiga pada interval waktu tertentu [5]. Sedangkan metode Webhook akan mengirimkan informasi ke pihak ketiga secara langsung ketika informasi tersebut diterima oleh Bot Engine Telegram [5]. Sebagai gambaran berikut merupakan perbandingan metode menggunakan Long Polling dan Webhook.

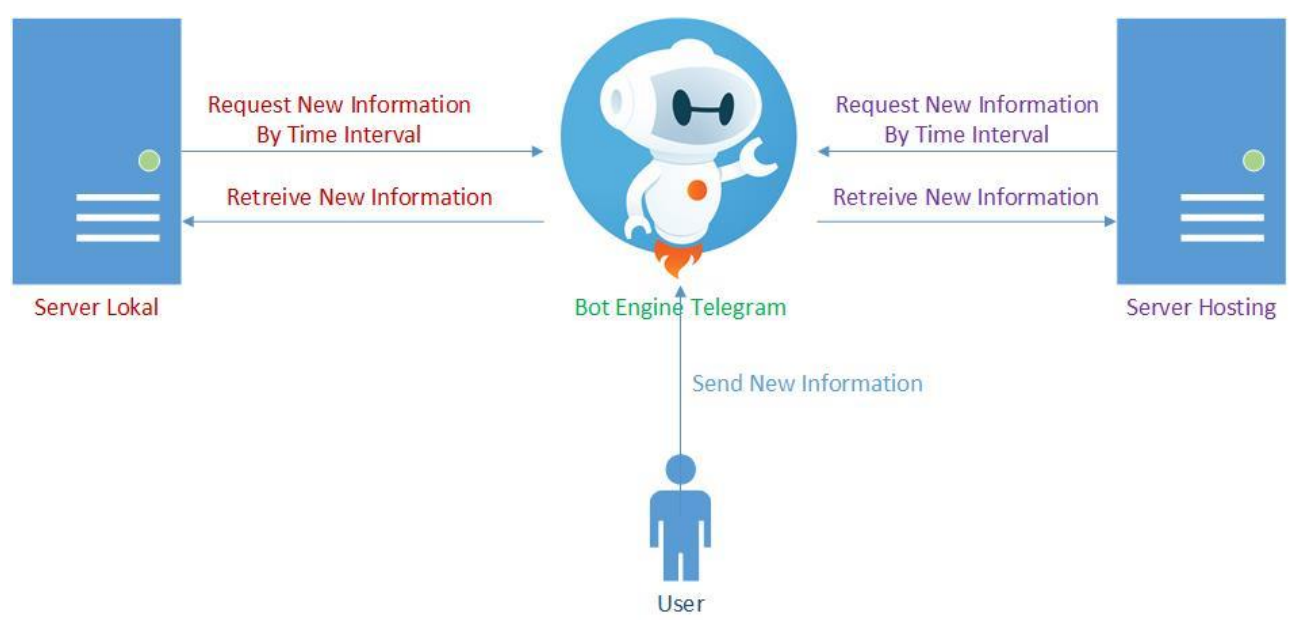

Gambar 1. Metode Long Polling Bot Engine Telegram

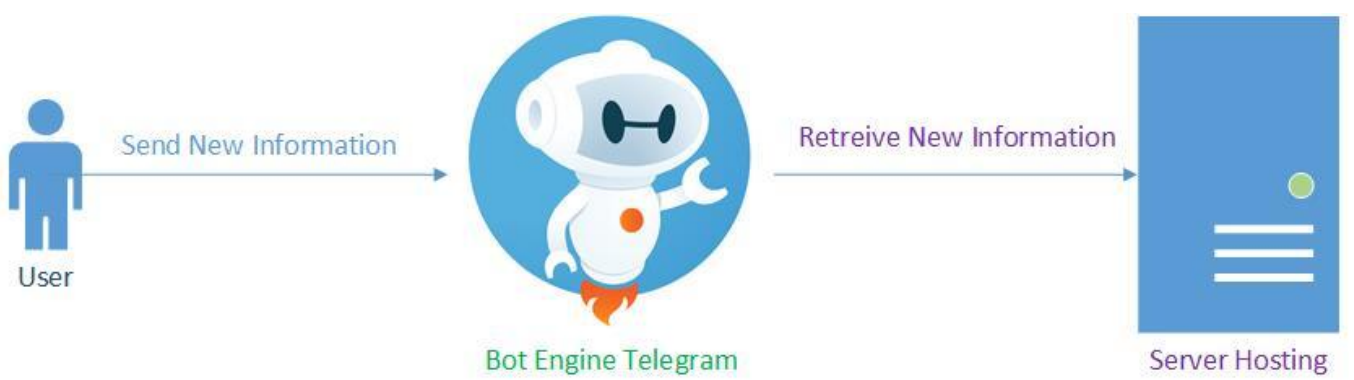

Gambar 2. Metode Webhook Bot Engine Telegram

Teknologi Bot Engine ini memungkinkan pengguna layanan E-Goverment dapat mengakses, mengajukan dan menerima layanan dari pemerintahan ditingkat desa. Dengan adanya sistem ini diharapkan dapat melengkapi pelayanan konvensional maupun pelayanan lain yang sudah ada sehingga dapat menjadi pilihan pelayanan yang berguna untuk mempersingkat waktu baik pemberi layanan maupun pengguna layanan dalam kegiatan E-Government, mengurangi beban kerja pemberi layanan, memudahkan kontrol dan penanganan keluhan, mengurangi kemungkinan keterlibatan oknum-oknum yang bermaksud buruk, dan secara tidak langsung meningkatkan kepercayaan masyarakat akan lembaga pemerintahan di Indonesia. 


\section{METODE PENELITIAN}

Metode yang dilakukan dalam penelitian ini adalah metode Research \& Development (R\&D). Metode Research \& Development adalah metode penelitian yang dipakai untuk menghasilkan produk tertentu, dan menguji keektifan produk tersebut. Agar bisa menghasilkan suatu produk tertentu yang dipakai untuk penelitian yang bersifat analisis kebutuhan (digunakan metode survey) dan untuk menguji keefektifan produk tersebut supaya bisa berfungsi di masyarakat luas, maka diperlukan penelitian guna menguji keektifan produk tersebut (digunakan metode eksperimen) [6]. Metode ini memiliki prototype produk yang sebagai hasil dari penelitian. Salah satu model R\&D yaitu Metode R\&D yang dikembangkan oleh Borg dan Gall (1989) dengan tahapan sebagai berikut

a. Penggalian Informasi dan Pengumpulan Data

Pada tahapan ini dilakukan beberapa studi awal sebagai basis dari tahapan yang akan datang.

Yang pertama adalah tahapan studi literatur yaitu peng-kajian akan hal-hal yang berkaitan dengan Bot Engine Telegram serta layanan-layanan dalam E-Government. Studi berikutnya adalah studi lapangan yang berupa proses analisis kebutuhan informasi yang berkaitan dengan layanan-layanan E-Government

b. Perencanaan

Tahapan ini meliputi proses merumuskan permasalahan, tujuan, mengembangkan bentuk permulaan (prototype) awal sistem Bot Engine yang akan dibangun dan dikembangkan.

c. Pre-Eliminary Field Testing

Pada tahapan ini dilakukan pengujian awal sistem secara terbatas. Uji coba dilakukan dengan metode Blackbox dan Whitebox [7]

d. Main Product Revision

Pada tahapan ini dilakukan perbaikan atas beberapa kesalahan yang ditemukan pada tahapan sebelumnya. Tujuan dilakukan tahapan ini adalah menyempurnakan sistem yang telah dirancang agar tidak melenceng dari perencanaan sebelumnya.

e. Main Field Testing

Pada Tahapan ini dilakukan pengujian secara menyeluruh terhadap seluruh fitur setelah diimplementasikan dilapangan

\subsection{Perancangan Sistem}

Sistem Bot Engine yang akan dibangun merupakan pengembangan platform dari Sistem Informasi Administrasi Desa (SIADES) yang telah digunakan di desa Sumbermulyo Kecamatan Jogoroto Kabupaten Jombang [8]. Sistem yang dirancang berupa Bot Engine yang akan dikonfigurasi pada Server Telegram. Secara visual Bot Engine menyerupai group chat yang nanti akan muncul di aplikasi Telegram. Dalam tampilan Bot Engine tersebut terdapat pilihan layanan yang dapat digunakan oleh warga. Layanan tersebut dibagi menjadi 2 jenis yaitu layanan data dan layanan surat.

Dalam layanan data warga yang ingin mengunakan layanan e-government berbasis Telegram Bot Engine harus menginstal terlebih dahulu aplikasi Instan Messaging Telegram. Setelah berhasil menginstal, maka warga dapat menggunakan Layanan Bot Engine desa Sumbermulyo. Setelah masuk Bot layanan, sistem akan melakukan pemeriksaan apakah yang bersangkutan telah/belum terdaftar dalam SIADES, jika telah terdaftar maka menu layanan akan muncul. Jika belum terdaftar, maka hanya pilihan registrasi yang muncul. Registrasi menggunakan kombinasi NIK (Nomor Induk Kependudukan) dan Nomor KK (Kartu Keluarga). Dalam menggunakan layanan data, warga cukup memilih layanan data yang diinginkan kemudian sistem akan memproses dan mencari data yang diinginkan. Jika data tersedia maka data tersebut akan dikirimkan kembali ke warga melalui Bot Layanan. Jika data tidak tersedia, maka sistem akan mengirimkan pesan khusus sesuai data tersebut ke warga melalui Bot Layanan. Alur layanan ini digambarkan sebagai berikut 


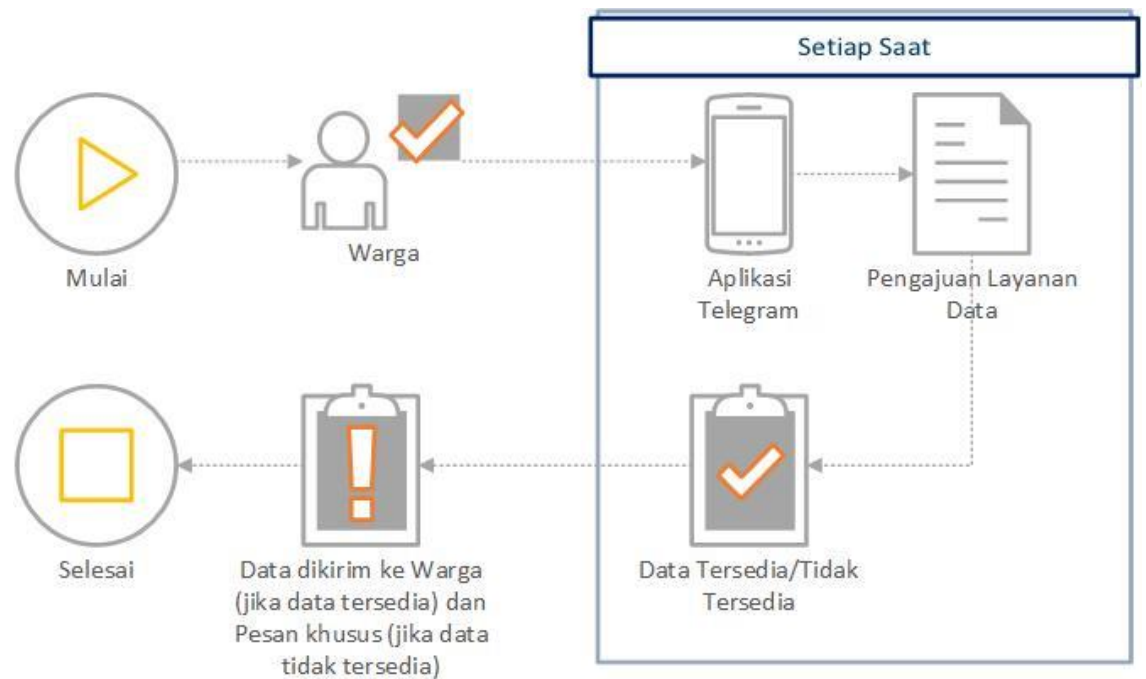

Gambar 3. Alur Sistem Layanan Data e-Government berbasis Telegram Bot Engine

Warga yang ingin mengunakan layanan e-government berbasis Telegram Bot Engine harus menginstal terlebih dahulu aplikasi Instan Messaging Telegram. Setelah berhasil menginstal, maka warga dapat menggunakan Layanan Bot Engine desa Sumbermulyo. Setelah masuk Bot layanan, sistem akan melakukan pemeriksaan apakah yang bersangkutan telah/belum terdaftar dalam SIADES, jika telah terdaftar maka menu layanan akan muncul. Jika belum terdaftar, maka hanya pilihan registrasi yang muncul. Registrasi menggunakan kombinasi NIK (Nomor Induk Kependudukan) dan Nomor KK (Kartu Keluarga). Dalam menggunakan layanan data, warga cukup memilih layanan data yang diinginkan kemudian sistem akan memproses dan mencari data yang diinginkan. Jika data tersedia maka data tersebut akan dikirimkan kembali ke warga melalui Bot Layanan. Jika data tidak tersedia, maka sistem akan mengirimkan pesan khusus sesuai data tersebut ke warga melalui Bot Layanan. Alur layanan ini digambarkan sebagai berikut

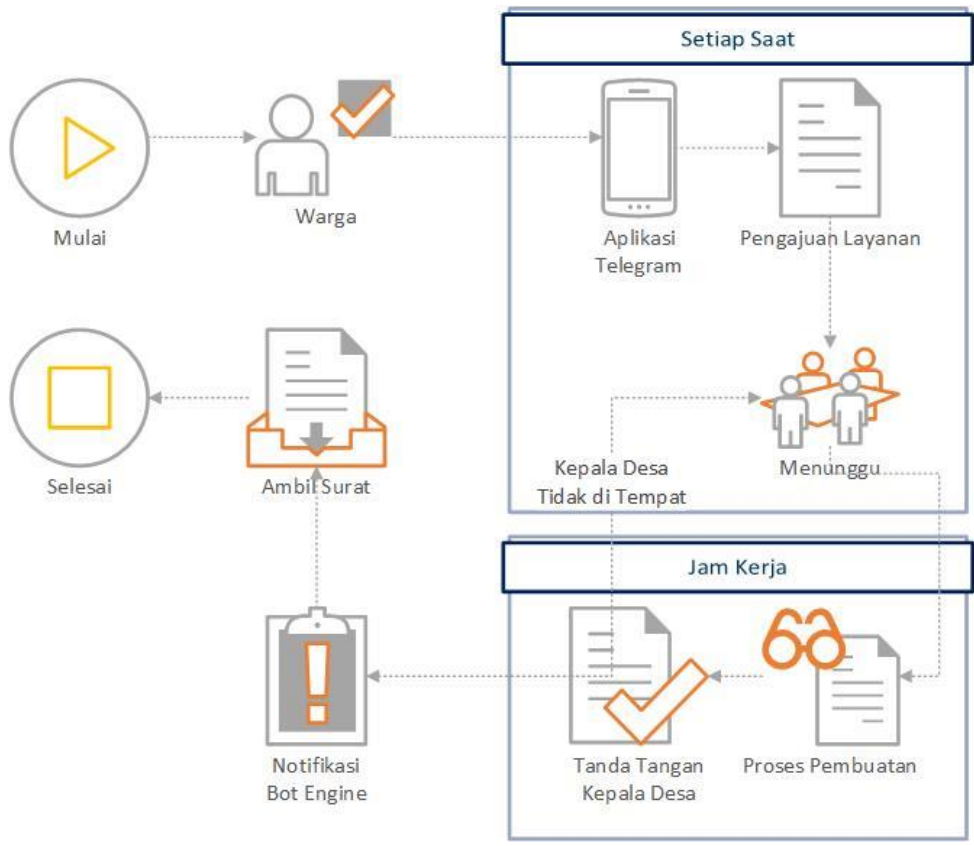

Gambar 4. Alur Sistem Layanan Surat $e$-Government berbasis Telegram Bot Engine [9] 


\subsection{Perancangan Layanan}

Beberapa jenis layanan yang dirancang untuk ditempatkan pada E-Government berbasis Layanan Bot Engine Telegram antara lain:

a. Layanan Data

Layanan Data terdiri dari layanan data pribadi (biodata), layanan data keluarga, layanan data program keluarga harapan $(\mathrm{PKH})$, layanan data bantuan pangan non tunai (BPNT) dan layanan data kartu indonesia sehat (KIS)

b. Layanan Surat

Layanan Surat terdiri dari layanan surat keterangan usaha, surat keterangan domisili, surat keterangan catatan kepolisian, surat keterangan belum pernah nikah dan surat keterangan umum.

\subsection{Perancangan Basis Data}

Pada penelitian ini perancangan basis data lebih terfokus pada konsep integrasi sistem sehingga basis data dibagi menjadi 2 yaitu basis data tambahan dalam rangka integrasi antara Layanan Bot Engine dengan SIADES dan basis data milik SIADES yang berhubungan dengan fitur dalam Layanan Bot Engine. Basis data tambahan ditempatkan pada server lokal dimana SIADES berjalan

Tabel 1. Rancangan Tabel Login External

\begin{tabular}{|c|l|l|c|}
\hline No & \multicolumn{1}{|c|}{ Kolom } & \multicolumn{1}{c|}{ Tipe Data } & \multicolumn{1}{c|}{ Status } \\
\hline 1 & NIK & Char (16) & Primary Key \\
\hline 2 & KK & Char (16) & \\
\hline 3 & Udid & Varchar (100) & \\
\hline 4 & ID_Telegram & Varchar (100) & \\
\hline 5 & PIN & Text & \\
\hline
\end{tabular}

Tabel 2. Rancangan Tabel Aktifitas Bot

\begin{tabular}{|c|l|l|l|}
\hline No & \multicolumn{1}{|c|}{ Kolom } & \multicolumn{1}{c|}{ Tipe Data } & Status \\
\hline 1 & ID & Char (25) & Primary Key \\
\hline 2 & ID_Telegram & Varchar (100) & \\
\hline 3 & Jenis & Varchar (100) & \\
\hline 4 & Aktifitas1 & Text & \\
\hline 5 & Aktifitas2 & Text & \\
\hline 6 & Aktifitas3 & Text & \\
\hline 7 & Aktifitas4 & Text & \\
\hline 8 & Aktifitas5 & Text & \\
\hline 9 & Status & Char (2) & \\
\hline 10 & Waktu & Datetime & \\
\hline
\end{tabular}

\section{HASIL DAN ANALISA}

Penelitian ini menghasilkan inovasi yang merubah cara kerja sistem E-Government lama yang (birokratis) dimana warga diharuskan untuk mengantri lama sedangkan kinerja dari pegawai pemerintah dianggap masyarakat "rendah" yang mengakibatkan ketidakpuasan warga terhadap layanan E-Government. Perubahan sistem yang baru menjadi lebih cepat karena waktu tunggu warga tidak dihabiskan dengan menunggu di tempat atau kantor pemerintahan sehingga mereka dapat beraktivitas secara normal tanpa terganggu. Hal ini dapat diwujudkan dengan E-Government dimana warga dapat mengakses layanan darimana saja selama mereka terkoneksi dengan jaringan internet menggunakan perangkat yang umum digunakan oleh masyarakat. Inovasi yang diterapkan ini memberikan nilai ekonomi bagi warga dimana aktifitasnya tidak terganggu sehingga meningkatkan kepuasan pengguna layanan, meningkatkan kualitas kinerja pegawai pemerintahan yang terkait dengan adanya otomatisasi serta terukurnya kinerja para pegawai tersebut karena permintaan dan pelayanan terdata sehingga dapat diobservasi dengan angka yang sesuai data di lapangan. 
Aplikasi yang dihasilkan dari penelitian ini berupa pemanfaatan fitur Bot Engine pada aplikasi Instant Messaging Telegram yang umum dipakai di masyarakat. Implementasi dari Bot Engine ini dengan menempatkan sebuah API pada Server Online yang bertugas menangani request yang berasal dari Telegram Bot Engine secara langsung. Request tersebut akan diteruskan ke API yang ditempatkan pada server lokal. API pada server lokal yang akan memproses secara langsung request tersebut berdasarkan akses yang diberikan oleh SIADES pada data-data tertentu sesuai dengan layanan yang dibutuhkan. Setelah hasil diperoleh maka API pada server lokal akan mengirim data hasil layanan ke API pada server online yang kemudian diteruskan kembali ke Telegram Bot Engine sebagai hasil request. Berikut hasil implementasi Layanan Bot Engine pada platform Telegram

Pada dasarnya layanan Bot Engine berjalan pada platform Telegram sehingga dilakukan instalasi aplikasi Telegram telebih dahulu pada Smartphone Android. Kemudian pada aplikasi telegram gunakan fitur pencarian dengan keyword sumbermulyojbg_bot. Setelah ditemukan dalam list pencarian cukup ditekan sehingga menghasilkan tampilan sebagai berikut:

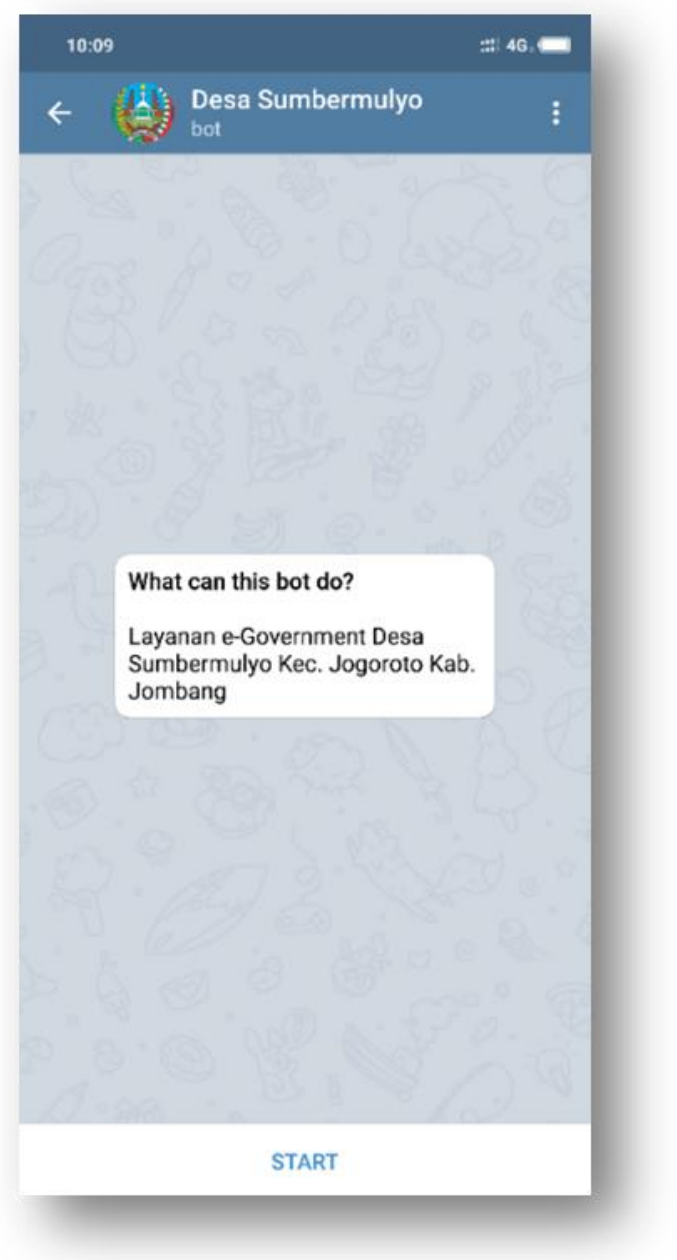

Gambar 5. Tampilan Awal Layanan Bot Engine pada Platform Telegram

Dengan menekan tombol Start dan Layanan Bot Engine akan mendeteksi apakah ID Telegram Pengguna tersebut telah terdaftar pada Layanan atau belum. Jika telah terdaftar, maka akan muncul jenis-jenis layanan yang dapat digunakan seperti gambar berikut ini 


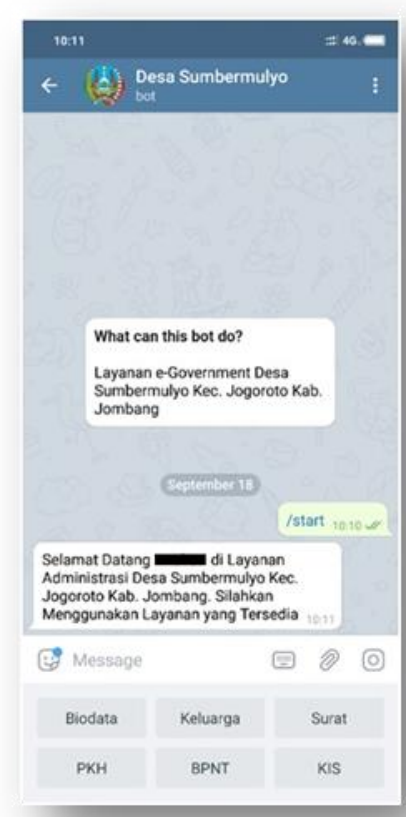

Gambar 6. Tampilan Daftar Layanan Bot Engine saat pengguna telah terdaftar (data di sensor karena menggunakan data asli)

Pengguna yang terdaftar cukup menggunakan salah satu jenis Layanan Bot Engine berikut saat penggunaan layanan Biodata. Layanan ini bertujuan untuk memastikan bahwa data yang bersangkutan telah sesuai di database kependudukan pemerintah tingkat desa. Data yang dimunculkan berupa biodata lengkap yang bersangkutan

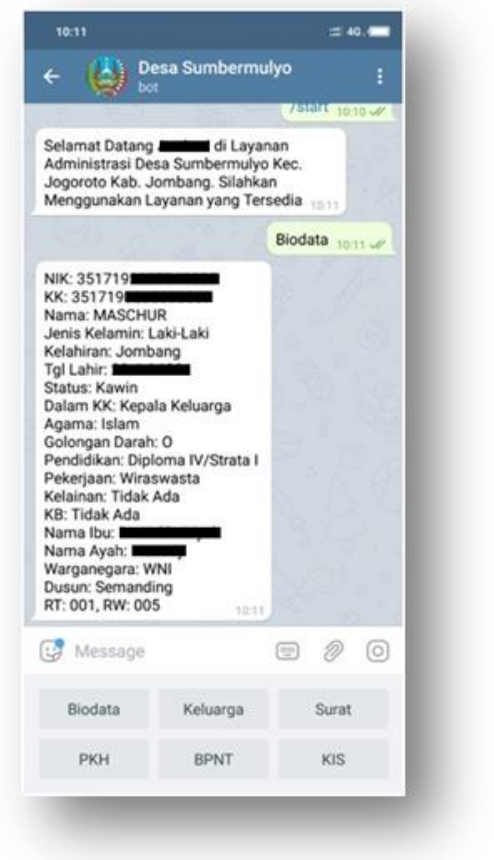

Gambar 7. Tampilan hasil layanan pada fitur Biodata (data di sensor karena menggunakan data asli) 
Fitur lainnya yaitu fitur layanan Data Keluarga. Fitur ini bertujuan untuk memastikan bahwa data pada kartu keluarga yang bersangkutan telah sesuai di database kependudukan pemerintah tingkat desa. Data yang dimunculkan berupa biodata lengkap dari masing-masing anggota keluarga

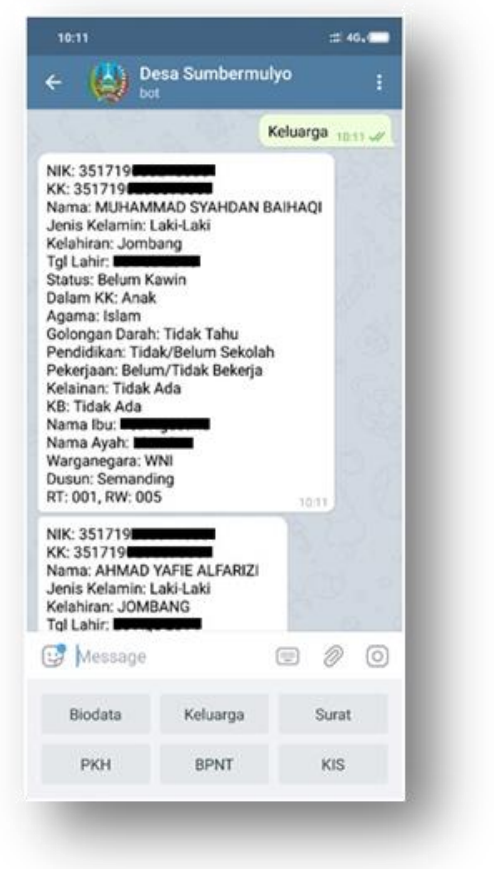

Gambar 8. Tampilan hasil layanan pada fitur Keluarga (data di sensor karena menggunakan data asli)

Fitur berikutnya adalah fitur layanan Surat. Fitur ini bertujuan untuk melayani surat-surat administratif yang dibutuhkan oleh warga sesuai dengan kebutuhannya

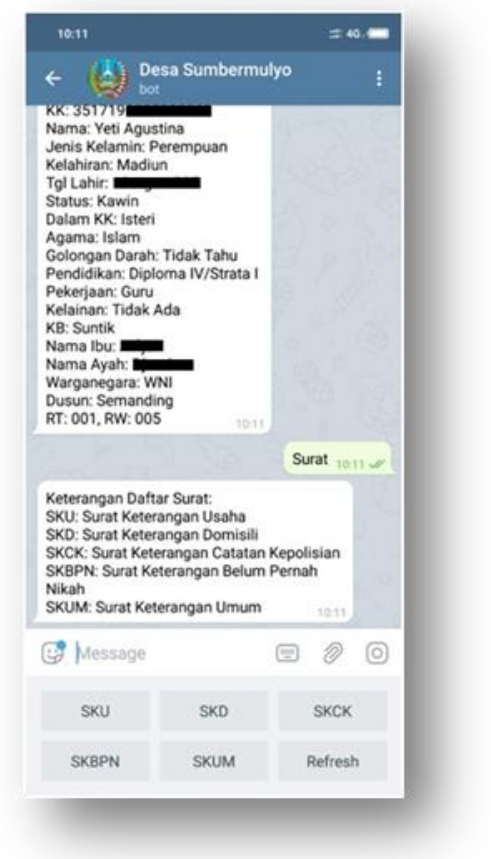

Gambar 9. Tampilan hasil layanan Surat (data di sensor karena menggunakan data asli) 


\section{KESIMPULAN DAN SARAN}

Setelah melaksanakan penelitian tentang pengembangan Bot Engine Telegram dengan metode Webhook dalam layanan E-Government ini maka dapat disimpulkan sebagai berikut:

a. Sistem yang dibangun dapat mempersingkat waktu layanan dikarenakan semua request dilakukan melalui sistem khusus kapan saja dan dimana saja tanpa menyita waktu produktif warga yang berkepentingan.

b. Dapat meminimalisir penyebaran virus Covid-19 dikarena tidak ada lagi antrian secara fisik.

c. Layanan E-Government terdiri dari 2 jenis yaitu layanan data dan layanan surat. Layanan data terdiri dari biodata, biodata keluarga, data Program Keluarga Harapan (PKH), data Bantuan Pangan Non Tunai (BPNT) dan Kartu Indonesia Sehat (KIS). Sedangkan layanan surat terdiri dari surat keterangan usaha, surat keterangan domisili, surat keterangan catatan kepolisian, surat keterangan belum pernah nikah dan surat keterangan umum.

d. Layanan Bot Engine berjalan pada platform Telegram sehingga jika ingin menggunakannya harus menginstal aplikasi telegram terlebih dahulu.

Saran yang dapat disusun setelah melakukan penelitian ini antara lain

Diharapkan ke depan dapat memperluas jenis layanan E-Government seperti layanan Surat

Pemberitahuan Pajak Terhutang Pajak Bumi dan Bangunan (SPPT PBB), Layanan pengumuman kegiatan, mempersingkat layanan surat berbasis tanda tangan elektronik.

\section{ACKNOWLEDGEMENTS}

Penulis sampaikan terima kasih yang sebanyak-banyaknya terhadap RISTEKBRIN yang memberikan pendanaan penelitian dalam skema Penelitian Dosen Pemula sehingga penelitian ini dapat terlaksana dengan baik.

\section{DAFTAR PUSTAKA}

Anshori Aris Widya, Moh. Agustiawan, Yosi. Dwi Fibrian, Ivan. Muttaqin, Zainal. 2016. "Upaya Peningkatan Pelayanan Administrasi Kependudukan Menggunakan Teknologi Informasi: Rancang Bangun Sistem Informasi di Desa Sumbermulyo Kecamatan Jogoroto Kabupaten Jombang”. REGISTER Jurnal Ilmiah Teknologi Sistem Informasi Vol. 2, No. 2. ISSN: 25030477

Anshori Aris Widya, Moh. Indra Sensuse, Dana. 2017. "Model Mobile Computing Untuk Meningkatkan Layanan E-Government di Tingkat Desa". SAINTEKBU Jurnal Sains dan Teknologi Vol. 9 No. 2. ISSN: 2541-1942.

Cokrojoyo, Anggiat. Andjarwirawan, Justinus. Noertjahyana, Agustinus. 2017. "Pembuatan Bot Telegram untuk Mengambil Informasi dan Jadwal Film Menggunakan PHP”. Jurnal Infra. Vol. 5. No. 1

Hanif Al Fatta. 2007. “Analisis dan Perancangan Sistem Informasi”. Yogyakarta: Andi Publisher https://core.tele gram.org/api, diakses tanggal 15 Agustus 2019

https://core .tele gram.org/bots/api, diakses tanggal 15 Agustus 2019

Saribekyan, Hayk dan Margvelashvili, Akaki. 2017."Security Analysis of Telegram". Diakses tanggal 15 Agustus 2019.

Sugiyono. 2007. "Metode Penelitian Kuantitatif, Kualitatif dan R\&D. Bandung: Alfabeta

Zuliarso, Eri. Februariyanti, Herny. 2013. "Pemanfaatan Instant Messaging untuk Aplikasi Layanan Akademik". Jurnal Teknologi Informasi DINAMIK Vol. 18, No. 2, ISSN: 08549524. 